\title{
NITROGEN FIXATION BY WOODY PLANT SPECIES AS MEASURED BY ACETYLENE REDUCTION ASSAY
}

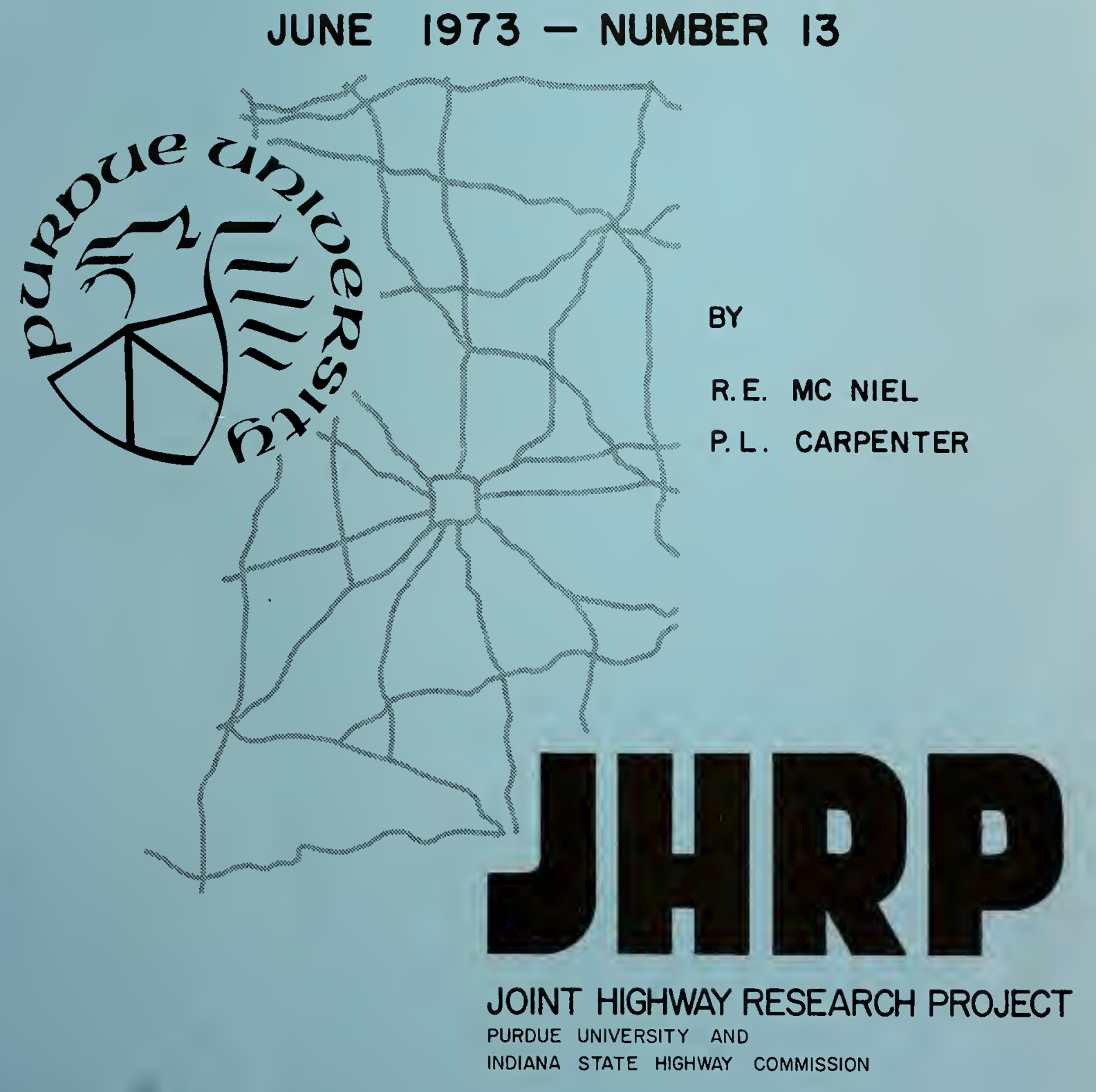



NITROGEN FIXATION BY WOODY PLANT SPECIES AS MEASURED

BY ACETYLENE REDUCTION ASSAY

\author{
by \\ Robert E. McNie1 \\ Graduate Assistant in Research \\ and \\ Philip L. Carpenter \\ Associate Professor \\ Department of Horticulture \\ Joint Highway Research Project \\ Project No.: C-36-48C \\ File No.: $9-5-3$ \\ Prepared as Part of an Investigation \\ Conducted by \\ Joint Highway Research Project \\ Engineering Experiment Station \\ Purdue University \\ In cooperation with the \\ Indiana State Highway Commission \\ and the \\ U.S. Department of Transportation \\ Federal Highway Administration
}

The contents of this report reflect the views of the author who is responsible for the facts and the accuracy of the data presented herein. The contents do not necessarily reflect the official views or policies of the Federal Highway Administration. This report does not constitute a standard, specification, or regulation.

Purdue University

West Lafayette, Indiana

June 13, 1973 
Digitized by the Internet Archive in 2011 with funding from

LYRASIS members and Sloan Foundation; Indiana Department of Transportation 
NITROGEN FIXATION BY WOODY PLANT SPECIES AS MEASURED BY ACETYLENE REDUCTION ASSAY

TO: J. F. McLaughlin, Director Joint Highway Research Project

FROM: H. L. Michae1, Associate Director Joint Highway Research Project
June 13,1973

Project: C-36-48C

File: $9-5-3$

The attached is a Technical paper from Part II of the HPR Research Project "Research in Roadside Development and Maintenance". This Paper is titled "Nitrogen Fixation by Woody Plant Species as Measured by Acetylene Reduction Assay" and has been authored by Messrs. Robert E. McNiel and Philip L. Carpenter. It is from the Interim Report published in July 1972 as J.H.R.P. Report Number 13.

The Paper is submitted for approval of publication in the Journal of the American Society for Horticulture Science. It will also be submitted to the ISHC and the FHWA for comment and information.

Respectfully submitted,

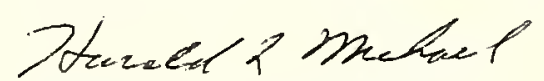

Harold L. Michael

Associate Director

HLM : ms

$\begin{array}{lll}\text { cc: W. L. Dolch } & \text { M. L. Hayes } & \text { C. F. Scholer } \\ \text { R. L. Eskew } & \text { C. W. Lovel1 } & \text { M. B. Scott } \\ \text { W. H. Goetz } & \text { G. W. Marks } & \text { J. A. Spooner } \\ \text { M. J. Gutzwiller } & \text { R. D. Miles } & \text { N. W. Steinkamp } \\ \text { G. K. Hallock } & \text { J. W. Miller } & \text { H. R. J. Walsh } \\ \text { R. H. Harre11 } & \text { G. T. Satterly } & \text { E. J. Yoder }\end{array}$




\title{
Nitrogen Fixation by Woody Plant Species as Measured by Acetylene Reduction Assay 1
}

\begin{abstract}
Robert E. McNiel and Philip L. Carpenter ${ }^{2}$
Purdue University, West Lafayette, Indiana
\end{abstract}

Abstract. Nodules from 13 woody plant species were analyzed by acetylene reduction assay to determine their nitrogen fixation activity. Activity was found with nodules from Caragana arborescens Lam., Robinia fertilis Ashe., R. hispida L., R. pseudoacacia L., Alnus glutinosa (L.) Graetn., Elaeagnus umbellata Thunb., E. angustifolia L., Shepherdia argentea Nutt., S. canadensis Nutt., H1ppophae rhamoides L., and Myrica pensylvanica Lofs. In addition, nodules from A. glutinosa were found to exhibit nitrogen fixation activity for at least 9 hours after having been excised from the plant. No active nodules were found on Comptonia peregrina (L.) Coult. or Cercis canadensis L.

\section{Received for publication . Journal paper no.} Purdue University Agricultural Experiment Station, West Lafayette, Indiana. Prepared as part of an investigation conducted by Joint Ifighway Research Project, Engineering Experiment Station, Purdue University in cooperation with the Indiana State Highway Commission and the U. S. Dept. of Transportation Federal Highway Administration.

2 Graduate Research Assistant and Associate Professor of Horticulture, respectively. 
Symbiotic nitrogen fixation occurs most abundantly in the Leguminosae although not all species have nodules. Approximately one-tenth of the 12,000 species of Leguminosae are known to develop nodular structures (1).

Symbiotic nitrogen fixation also occurs with less known frequency among 8 additional families containing 13 genera and 342 species, 118 of which are known to develop root nodules (13). The 13 genera include: Alnus, Arctostaphylos, Casuarina, Ceanothus, Cercocarpus, Coriaria, Discaria, Dryas, Elaeagnus, Hippophae, Myrica, Purshia, and Shepherdia. Nodular miterial on most legumes is spherical or cylindrical in shape with few or no lobes, while the individual nodule of nonlegumes are clusters of finger-like branches (6). Nodules of legumes are generally thought to be annual. The nonlegume nodules are perennial nnd with age may attain a diameter of several centimeters (6). However, in nodules from Myrica and Casuarina, the tip of the branch continues to produce a root of normal structure without nitrogen-fixing characteristics (7).

Nodules were identified on nonlegumes as early as 1892 (8). Early methods used to determine if nodule-bearing plants fixed nitrogen included determining the $\mathrm{N}$-content of the foliage on nodulated versus nonnodulated plants (15). Also, N-content of the foliage was determined for plants grown in solution-culture lacking $\mathrm{N}$ (11). Later, a method using ${ }^{15} \mathrm{~N}$ permitted the analysis of the quantity of nitrogen transformed by the following species: A. glutinosa $(3,4), \underline{H}$. rhamoides (3), S. canadensis (5), and Comptonia peregrina (17). 
With the development of the acetylene reduction assay (12), a method became available which permits rapid measurement of nitrogen fixation by nodules. The technique involves the reduction of acetylene to cthylene. The reduction of $\mathrm{N}_{2}$ to $\mathrm{NH}_{3}$ is believed to occur in a similar manner since the nitrogenase involved with nitrogen fixation has a range of specificity. Nodules from Alnus rugosa (DuRoi) Spreng., A. glutinosa, Myrica gale L., and Comptonia peregrina have been determined to be active by this method $(14,16)$.

The present study, part of a search for $\mathrm{N}$-fixing species for use in highway plantings, was to determine the nitrogen-fixing capabilities of several leguminous and nonleguminous woody plants.

ilaterials and Methods

Nitrogen-fixation capabilities were evaluated in 13 species. The species included 5 legumes (Robinia hispida, ㅅ․ fertilis, ‥ pseudoacacia, Caragana arborescens, and Cercis canadensis) and 8 nonlegumes (Elaeagnus umbellata, E. angustifolia, Shepherdia argentea, $\underline{\text { S. canadensis, }}$ Hippophae thamoides, Alnus glutinosa, Myrica pensylvanica, and Comptonia peregrina). Fixation was determined by acetylene reduction assay as determined by Davidson ${ }^{3}$ for those species that produced nodules.

3 Davidson, F. 1970. The influence of rhizoblal strain and soybean variety on leghemoglobin, hematin, nodule weights, and nitrogen fixation. Ph. D. Thesis, Purdue University, West Lafayette, Indiana. 
Plants were grown in the greenhouse in a sphagnum peat: horticultural grade perlite mixture $(1: 1 \mathrm{v} / \mathrm{v})$ or in the field. In no case was there an attempt to inoculate a plant that did not bear nodules.

Wilh nonlegumes, analyses were performed on detached nodules from plants 1 to 12 years old. Branched nodules were divided and only the iips were used; the base of the branch or center part of the cluster was discarded. Most legume nodules were left intact but if too large to enter an $18 \mathrm{ml}$ culture tube, they were divided. All nodule tips were washed with tap water to remove soll particles and then blotted dry in a paper towel prior to weighing.

Samples of detached nodules were generally taken during midmorning during the summer and fall of 1971. Of the various dates when samples were observed, Sept. 9 proved to be the most active for each species and only this date is reported.

Results and Discussion

Nitrogen fixation in legumes: Nodules obtained from 4 of the 5 species investigated (Caragana arborescens, Robinia fertilis, R. hispida, and R. pseudoacacia) reduced acetylene and therefore had N-fixing capability ( Fig. 1). Each reduced acetylene over a period of several hours which is longer than reported by Aprison (2) who found 2 he to be the maximum for excised soybean nodules. Cercis canadensis did not fix nitrogen since it does not form nodules (20). 
Nitrogen fixation by nonlegumes: Of the 8 species investigated, 7 (A. glutinosa, E. umbellata, E. angustifolia, $\underline{\text { S. argentea, }}$. $\underline{H}$. rhamnoides, and $\underline{M}$. pensylvanica) nodule-forming nonlegumes reduced acetylene and were classed as N-fixing species (Fig. 2). Comptonia peregrina had the remains of nodules which were no longer active. The length of netivity of detached nodules was determined with A. glutinosa. Nodules detached for $8 \mathrm{hr}$ still reduced acetylene during the next sampling hour (Fig. 3). This data agrees with data of Bond (3).

Nodule activity: There were color differences of nodules within and between speries. Color ranged from white to orange and from dull to bright. Within a species, brightness of the nodule irrespective of color was observed to be associated with high acetylene reduction. An example using E. angustifolia is shown in Fig. 4. 


\section{Literature Cited}

1. Alexander, M. 1967. Introduction to soil microbiology. John Wiley \& Sons, Inc., New York.

2. Aprison, M. H. and R. H. Burris. 1952. Time course of fixation of $\mathrm{N}_{2}$ by excised soybean nodules. Science 115:264-265.

3. Bond, G. 1955. An isotopic study of the fixation of nitrogen associated with nodulated plants of Alnus, Myrica, and Hippophae. Journ. Expt1. Bot. $6: 303-311$.

4. Bond, G. 1956. Evidence for fixation of nitrogen by root nodules of alder (Alnus). New Phyt. 55:147-153.

5. Bond, G. 1957. Isotopic studies of nitrogen fixation in non-legume root nodules. Ann. Bot. 21:513-521.

6. Bond, G. 1959. Fixation of nitrogen in non-legume root nodule plants. Soc. Exper. Biol. Symposia 13:59-72.

7. Bond, G. 1964. Isotopic investigations of nitrogen fixation in non-legume root nodules. Nature 204:600-601.

8. Bond, G. 1967. Fixation of nitrogen by higher plants other than legumes. Ann. Rev. Plant Physio1. 18:107-126.

9. Erdman, L. W. 1959. Legume inoculation, what it is--what it does . Farmers' Bulletin 2003. U. S. Dept. Agriculture, Washington, D. C.

10. Ferguson, T. P. and G. Bond. 1953. Observations on the formation and function of the root nodules of Alnus glutinosa (L.) Gaertn. Ann. Bot. 17:175-188. 
11. Gardner, I. C. 1958. Nitrogen fixation in Elaeagnus root nodules. Nature 181:717-718.

12. Hardy, R. W. F., R. D. Holsten, R. K. Jackson, and R. C. Burns . 1968. The acetylene-ethylene assay for $\mathrm{N}_{2}$ fixation: laboratory and field evaluation. Plant Physiol. 43:1185-1207.

13. Rodriquez-Barueco, C. 1968. The occurrence of nitrogen-fixing root nodules on non-leguminous plants. Bot. J. Linn. Soc. $62: 77-84$

14. Stewart, W. D. P., G. P. Fitzgerald, and R. H. Burris. 1967. In situ studies on $\mathrm{N}_{2}$ fixation using the acetylene reduction technique. Proc. Nat. Acad. Sci. 58:2071-2078.

15. Warren, J.A. 1910. Additional notes on the number and distribution of native legumes in Nebraska and Kansas. Bur. PI. Ind. Circ. 70. U. S. Dept. Agriculture, Washington, D. C.

16. Wheeler, C. T. 1969. The diurnal fluctuation in nitrogen fixation in the nodules of Alnus glutinosa and Myrica gale. New Phytol. $68: 675-682$.

17. Ziegler, H. and R. Huser. 1963. Fixation of atmosphertc nitrogen by root nodules of Comptonia peregrina. Nature 194:508. 


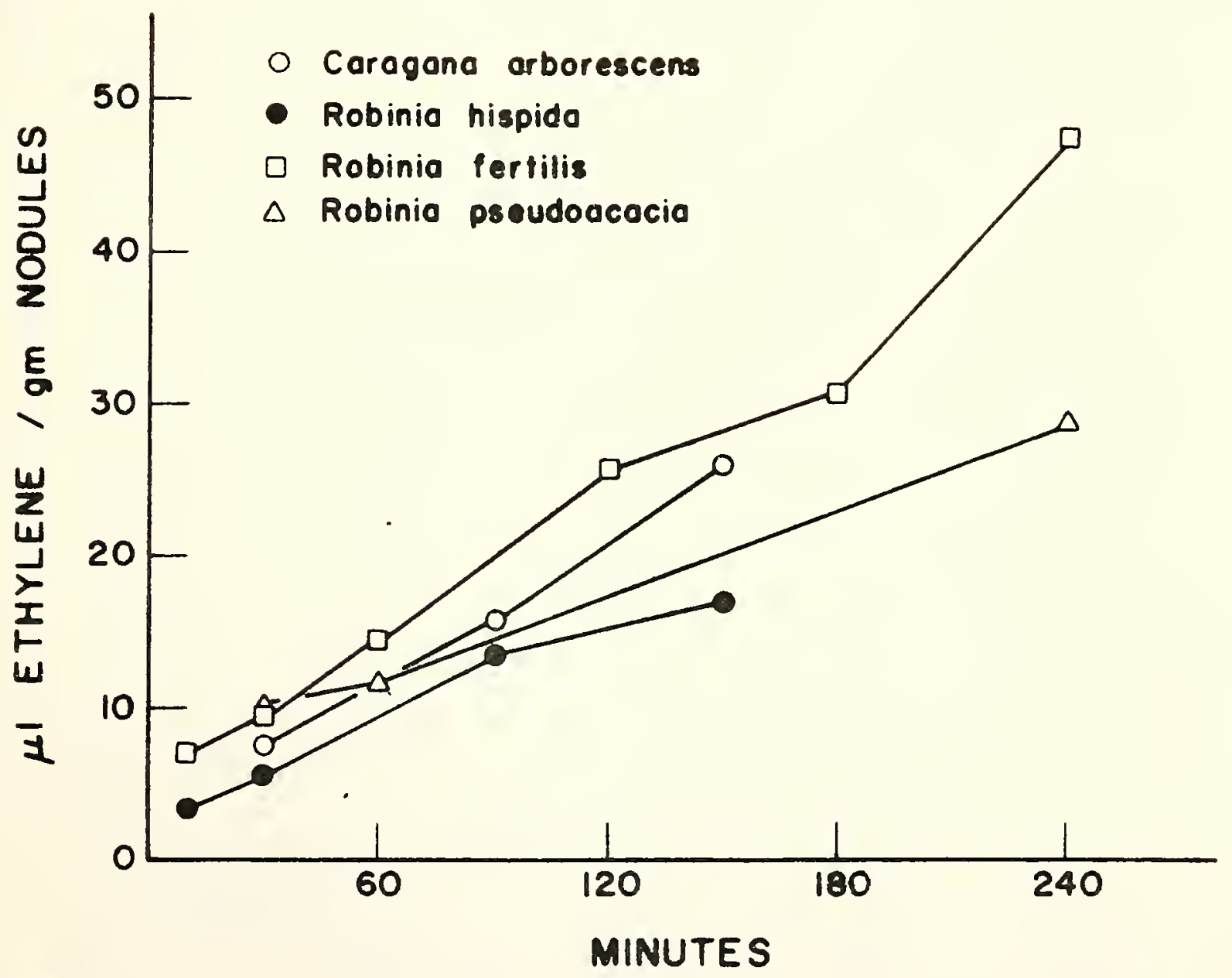

Figure 1. Reducition of acetylene by nodules. From field grown Caragana arborescens and Robinia hispida and from greenhouse grown

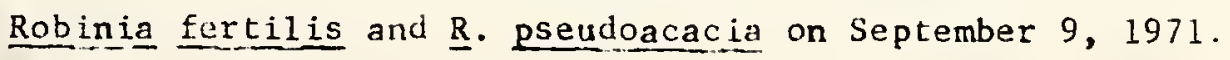




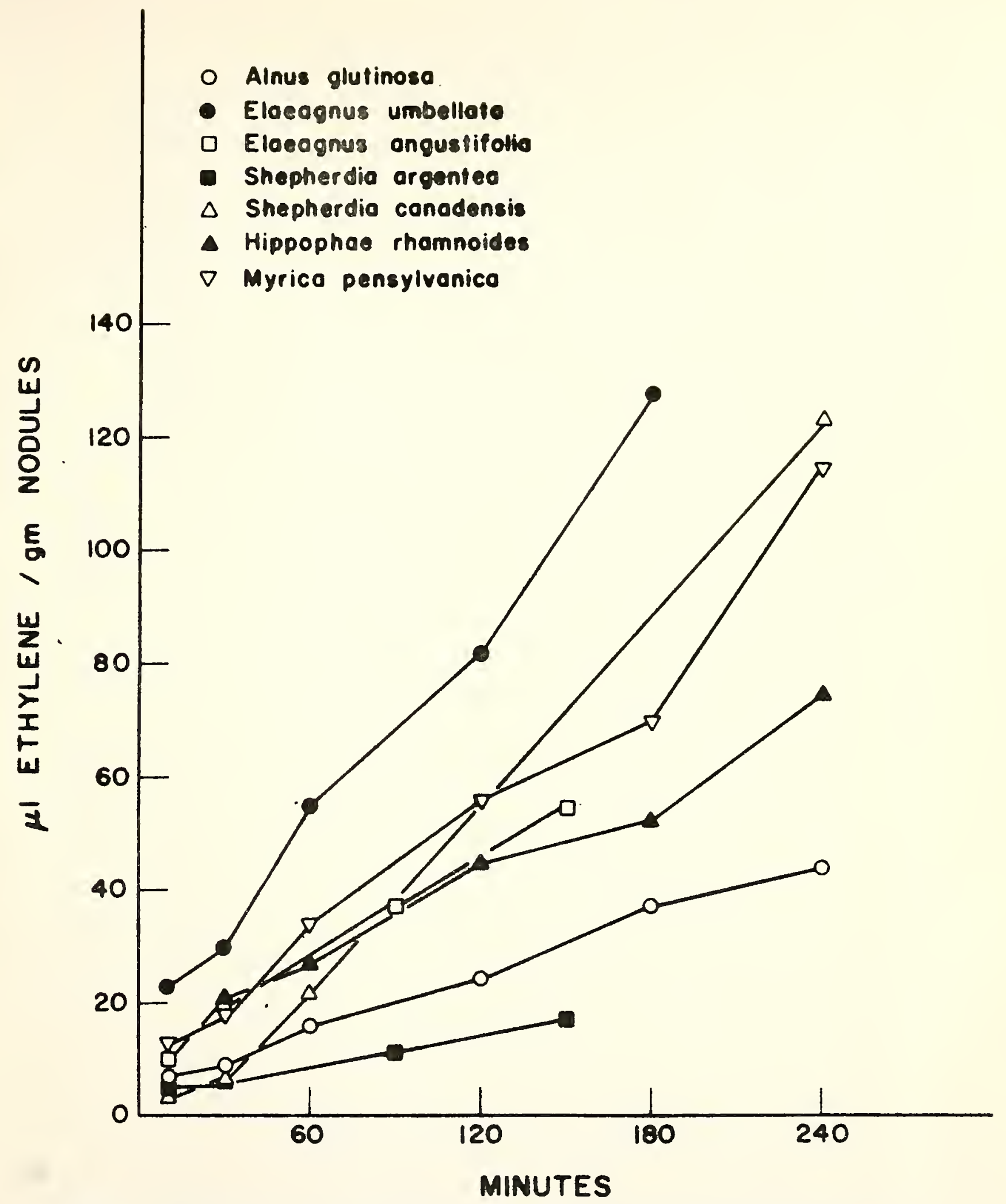

Figure 2. Reduction of acetylene by nodules from field grown Elaeganus angustifolia, Myrica pensylvanica, and Shepherdia argentea and from greenhouse grown Alnus glutinosa, Elaeagnus umbellata, Hippophae rhamoides, and Shepherdia canadensis on September 9, 1971. 


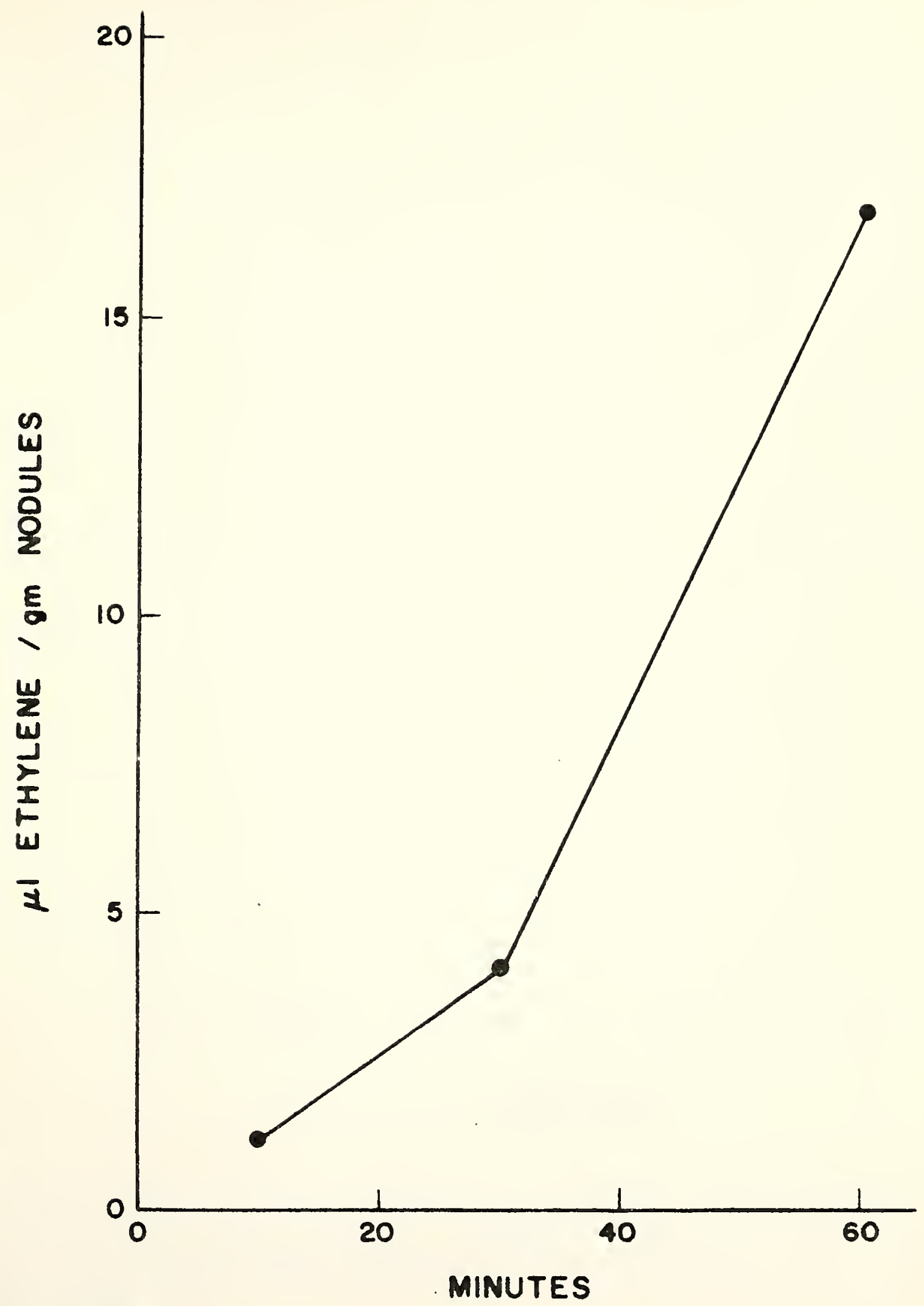

Figure 3. Reduction of acetylene by Alnus glutinosa nodules 8 hours after having been excised. 


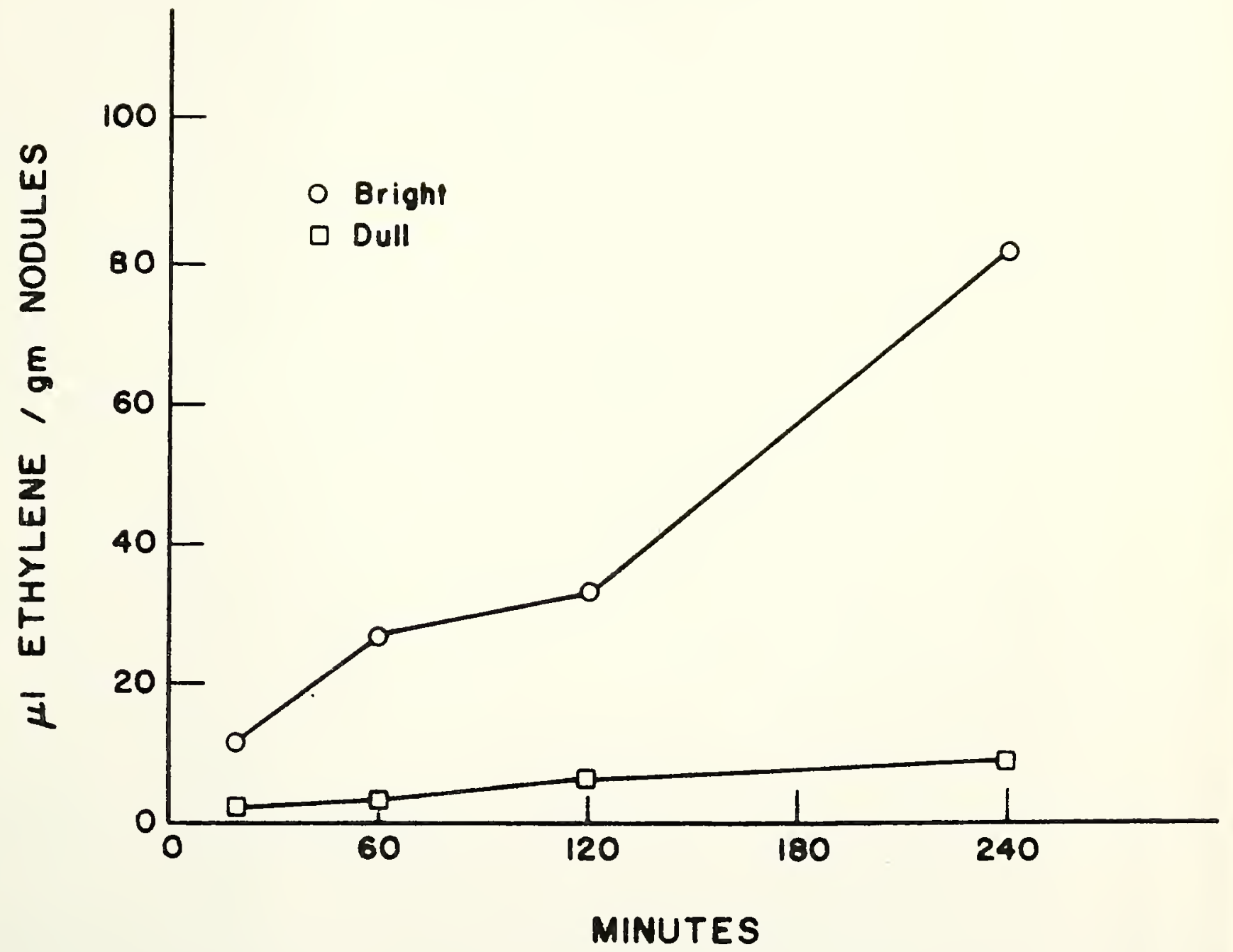

Figure 4. Reduction of acetylene by dull and bright nodules from field grown Elaeagnus angustifolia on July 14, 1971. 

